\title{
Recent seismicity of the «Acque Albule» travertine basin
}

\author{
Calvino Gasparini, Rosalba Di Maro, Nicola Mauro Pagliuca, Mario Pirro \\ and Alessandro Marchetti \\ Istituto Nazionale di Geofisica e Vulcanologia, Roma, Italy
}

\begin{abstract}
The seismic period which occurred in a portion of Guidonia Montecelio and Tivoli territory, two towns situated about twenty kilometres NE of Rome, affected four areas with a high density of population: Guidonia, Collefiorito, Villalba and Bagni di Tivoli. Even though the events had a very low magnitude (less than 3.0), local phenomena, like rumbles and strong vibrations of the ground, frightened inhabitants also because some months before (January 26, 2001) in a village named Marcellina situated a few kilometres away from Guidonia, a large sinkhole (600 m) had appeared without fore signals. The «Istituto Nazionale di Geofisica e Vulcanologia» (INGV) installed some digital stations that monitored the seismic phenomena. This paper has the aim to process all the information acquired during the period, both from the micro and macro seismic point of view, in order to explain the phenomenology that involved the area. The synergy of the two methodologies lead us to the conclusion that two different seismotectonic structures originated the events, one in an anti-apenninic direction, the other in a N-S direction.
\end{abstract}

Key words seismicity - neotectonic

\section{Introduction}

During the year 2001, a seismic sequence felt in the Acque Albule travertine basin, whose location is shown in figs. 1 and 2, aroused new interest in the area and geophysical studies have been carried out by INGV to explain the phenomenon.

From the geological point of view, the mentioned basin represents an interesting evaporitic deposit of continental origin. It is unique, in

Mailing address: Dr. Calvino Gasparini, Istituto Nazionale di Geofisica e Vulcanologia, Via di Vigna Murata 605, 00143 Roma, Italy; e-mail: gasparini@ingv.it
Central Italy, for the peculiar geo-mechanical characteristics and for the formation thickness (Cipriani et al., 1977).

The recent seismic phenomenology represents evidence of the tectonic instability of the area, probably connected to the travertine formation still in progress.

Another instability factor is probably represented by the presence of some sinkholes (small morphological depressions related to the breakdown of carbonate bedrock), whose origin is not clear yet so it is worth studying them to complete the geo-tectonic sketch of the area.

\section{Geological and structural settings}

The areas considered in this study are located in a plain inside the Acque Albule travertine basin, a few kilometres east of Rome, on the margin of the Central Tyrrhenian Sea (figs. 1 and 2). 


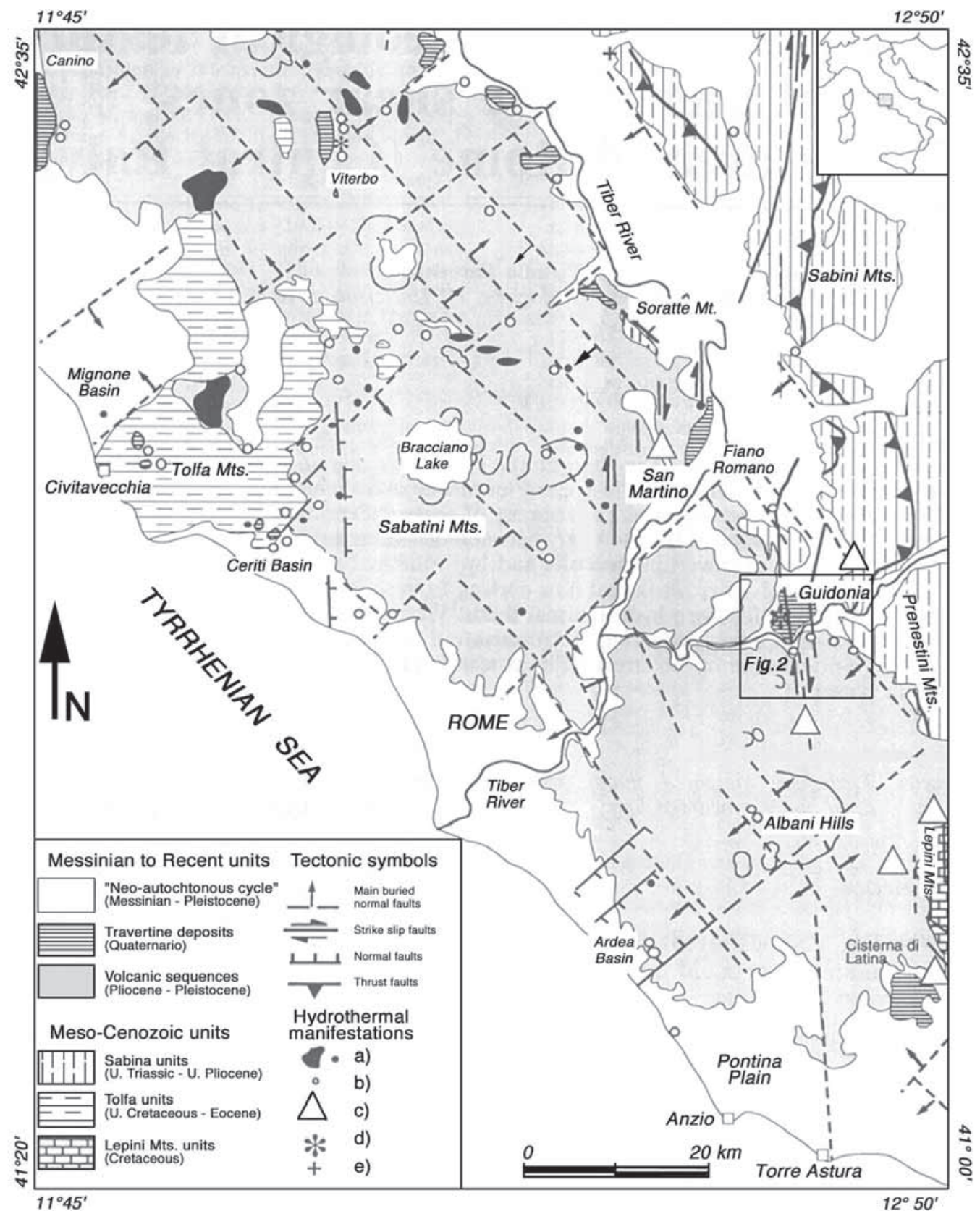

Fig. 1. Schematic map of the Latium Tyrrhenian margin and their correlation with the Acque Albule travertine basin. There are also many hydrothermal appearances: a) alunite and kaolin mineralization; b) leakages associated with small springs (with a temperature often up to $20^{\circ} \mathrm{C}$ ); c) groups of sinkholes; d) springs affected by hydrothermal activity $\left(T>20^{\circ} \mathrm{C}\right)$; e) mineralised springs (TDS $>0.75 \mathrm{~g} / \mathrm{l} ; T<20^{\circ} \mathrm{C}$ ). From Faccenna (1994) modified. 


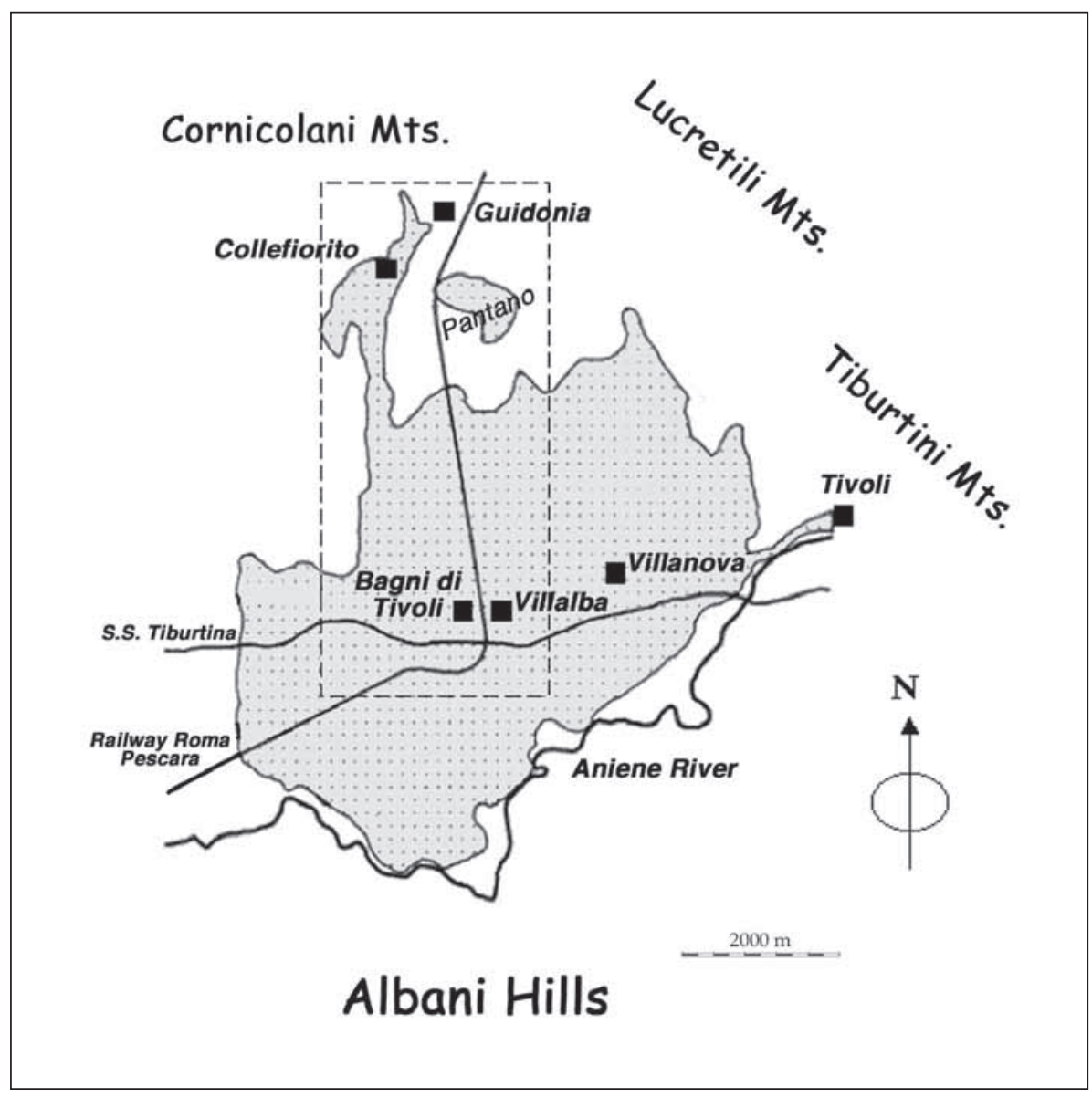

Fig. 2. Sketch map of Acque Albule travertine basin and location of the towns involved in this study.

Studies on this area go back to the end of the 19th century (Pellenti, 1882). Maxia in 1950 conducted the first geologic survey of such travertine formation (Maxia, 1950).

In fig. 3 the principal lithological sequence of the travertine basin is illustrated from top to bottom: a) whitish calcareous sand locally called testina or cappellaccio; b) ochre coloured travertine; c) greyish coloured ancient travertine; d) blue clay of Pliocene; e) marly limestone Mesozoic-Cenozoic. The stratigraphy has a generic character because the layer thickness is extremely variable across the area.
In particular, the sequence shows that the geological history of the Acque Albule travertine basin is related to the uplift of the Apennines. During the opening process of the Tyrrhenian Sea, about $5 \mathrm{Ma}$ ago, the western part of the Apennine chain was stretched and sank. Such sinking was not homogenous everywhere, some areas remained above the sea level, originating the Soratte and the Cornicolani mountains that constituted the horsts of the Tiberina graben (Ogniben et al., 1975). In that deep sea, an argillaceous material was initially deposited, originating the blue clay that crops out inside 


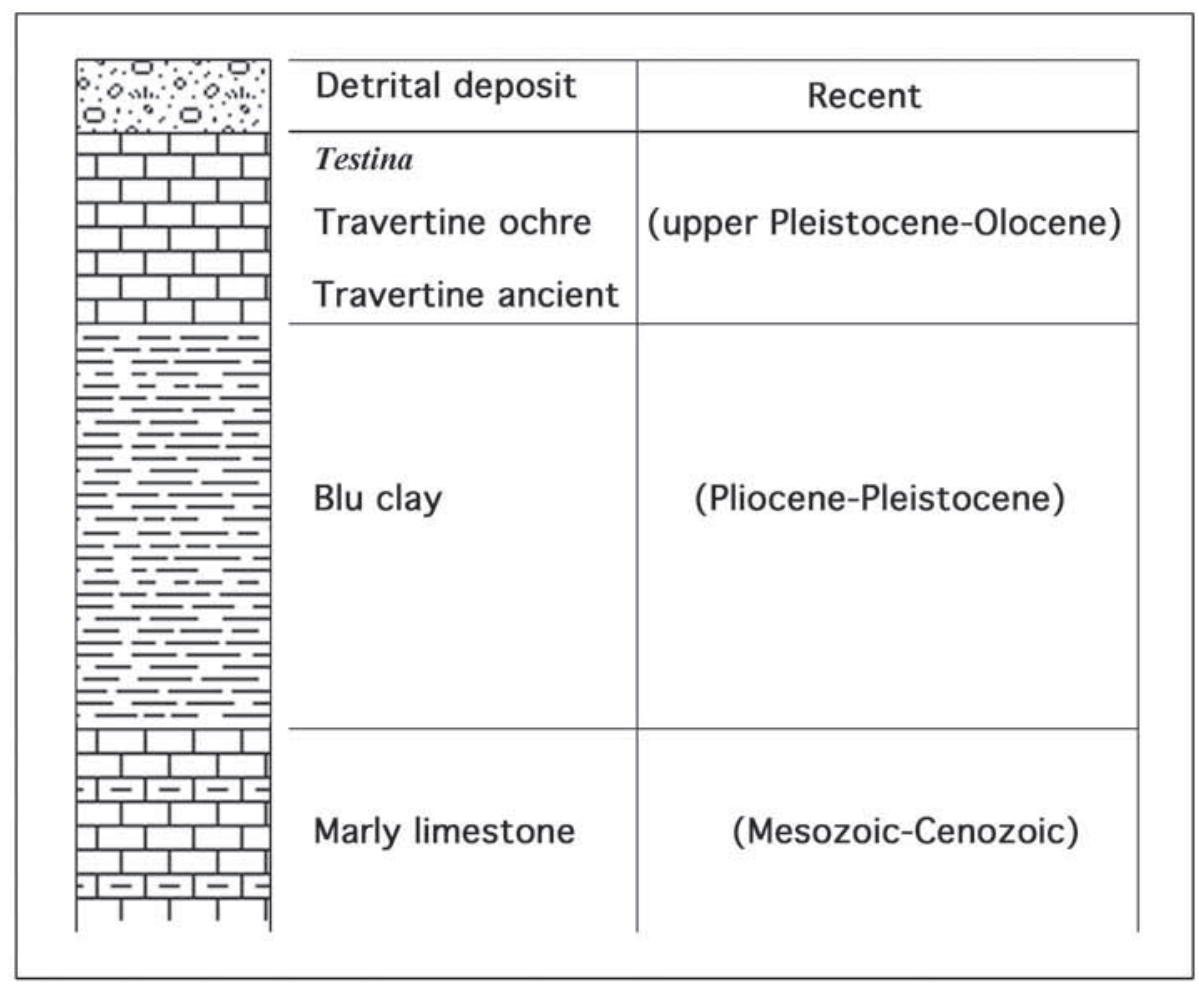

Fig. 3. Lithological sequence of the travertine basin. Notice that this scheme is purely indicative of the main lithotypes. Moreover the thicknesses is strongly dependent on the point.

Rome (close to the Vatican) and in the western part of Guidonia.

Subsequently, as a result of the uplift of this perithyrrenian area, the finest argillaceous material was replaced by yellowish sand, containing an elevated amount of coastal region organisms (Cosentino et al., 1990).

The strike-slip activity, from Pliocene through middle-upper Pleistocene, originated a series of $\mathrm{N}$-striking right-lateral en echelon fault segments, with a striking of $\mathrm{N}^{\circ} \mathrm{W}$ in the western part of the Acque Albule travertine basin (Faccenna and Funiciello, 1993; Faccenna et al., 1994). This tectonic setting starts from the southern Sabina, crosses the Cornicolani mountains, cuts the Aniene valley orthogonally in proximity to Pantano locality (figs. 1 and 2) and ends in the northern part of the Albani hills, a volcanic district located $20 \mathrm{~km}$ southeast of Rome. This volcanic district was active during the Pleistocene from about 0.7 to about $0.01 \mathrm{Ma}$, essentially with pyroclastic eruptions (Voltaggio and Barbieri, 1995).

During the upper Pleistocene, the formation of Acque Albule travertine basin began between Guidonia and the Aniene river (fig. 2). It is related to the latest magmatic manifestations of the Albani hills and tectonic strike-slip activity, however a tectonic structure trending $\mathrm{N} 30^{\circ}-45^{\circ} \mathrm{E}$ can be observed.

Such tectonic elements concur to interpret the area of Acque Albule as a pull-apart basin (Kearey and Frederik, 1990) characterized by a subsidence area that accommodated a lacustrine zone. Sulphur springs, over saturated by $\mathrm{CaCO}_{3}$, spurted out the extensional structures and caused 
the precipitation of carbonate and the travertine formation; this phenomenon is still in progress (Maxia, 1950).

Describing the geomorphological characteristics of the area, we can say that the Acque Albule travertine basin, with an extension of about $50 \mathrm{~km}^{2}$, spreads out from the shelter of the Cornicolani mountains ( $83 \mathrm{~m}$ a.s.l.) to the Aniene river (about $46 \mathrm{~m}$ a.s.1.). The NW area has an elevation of $100 \mathrm{~m}$ a.s.l. with a maximum elongation in the NE-SW direction, and it is connected with the travertine basin through an escarpment with a slope of $7.5 \%$. The morphologic differentiation of this area has a probable tectonic origin.

\section{The Guidonia seismic district}

In the second part of the 17 th century, a certain area of Collefiorito was named Valle stregata (Enchanted Valley) because the inhabitants were perceiving noises from the Earth.

Because of the scarcity of information, seismological characteristics are not well known in the Guidonia area, the low seismicity on one side and the recent urbanization on the other, did not allow the correct location of the events, that were put down as from the closest seismic zones.

Table I shows the most important events about which we have macro-seismic reports, the first one of which felt on May 22, 1972 at 1:15 a.m. (GMT).

The administrative manager of the municipal office reported that the event was felt by every- body including sleeping people. The event caused only rubble falling and cracks in the buildings, no victims or injured people, inhabitants heard a loud underground noise.

Three earthquakes, with an interval of 15-20 min between each other, were reported. On the basis of the description, the main shock was assigned an intensity of VI MCS degree.

Another seismic sequence, located in the Collefiorito area, during January 1989, had been characterized by a north-south migration of the hypocenters and the maximum intensity was $\mathrm{V}$ MCS degree, the affected area was small and narrow $\left(0.5 \mathrm{~km}^{2}\right)$, that could indicate very shallow depths (Meloni and Pirro, 1989).

On June 27, 1999 at 5:12 a.m. GMT (Pirro, 2002), an earthquake was felt only in the eastern part of the old town centre of Montecelio with an intensity of IV-V MCS degree. In this case, the INGV centralized network did not detect the event, meaning that it was very shallow.

Within a range of $20 \mathrm{~km}$ from the observed area, we do not find important seismogenetic structures. The Aniene valley is characterized by a moderate seismicity that rarely reaches VII MCS degree. In particular, during June 2000, a seismic sequence whose maximum duration magnitude was 4.0, caused damage in some historical towns located in the middle of Aniene valley (Rocca Canterano, Gerano, Cerreto Laziale, Canterano).

The southern part of Guidonia suffers from the effects of the Albani hills area, characterized by clustered events with low magnitude (maximum intensity: VIII MCS).

Table I. The most important events on which we have macro-seismic reports.

\begin{tabular}{lccccccc}
\hline \hline Year & Month & Day & $\begin{array}{c}\text { hh:mm } \\
(\mathrm{GMT})\end{array}$ & Lat. (N) & Long. (E) & MCS Int. & Localities \\
\hline 1972 & May & 22 & $01: 15$ & 41.99 & 12.72 & VI & Guidonia \\
1989 & January & 11 & $03: 30$ & 41.98 & 12.70 & IV-V & Collefiorito \\
1989 & January & 12 & $23: 00$ & 41.97 & 12.69 & V & Collefiorito \\
1989 & January & 13 & $22: 30$ & 41.97 & 12.69 & V & Collefiorito \\
1989 & January & 14 & $12: 20$ & 41.97 & 12.69 & V & Collefiorito \\
1999 & June & 27 & $05: 12$ & 42.02 & 12.73 & IV-V & Montecelio \\
\hline
\end{tabular}


Lastly, the north-western part of the area is also characterized by low seismicity. The main shock ( $I=$ VIII MCS) felt on April 24, 1901, injured Stazzano and Cretone towns (Postpischl, 1985).

\section{Macroseismic investigation and field observations}

To better characterize the whole phenomenon and the affected area, we performed detailed macroseismic investigations using an appropriate questionnaire, filled in directly by the inhabitants.

The first investigation concerned the event which occurred on June 22, 2001 at 4:36 p.m. GMT. Figure 4 shows in grey the area with the maximum intensity, about $200 \mathrm{~m}$ wide, extended in NNE-SSW direction for about $1 \mathrm{~km}$. In this area, whose intensity we attributed the V MCS degree, people heard the rumble, coming from the earth, and felt the quake at the same time. In the northern part, the noise was described as like a thunder coming from the sky. Everybody described the rumble as a deep sound and comparable to a collision between two trucks.

The larger area, shown in the figure, assessed as IV MCS degree, has an extension of about $2.5 \mathrm{~km}$ and about $300 \mathrm{~m}$ in width. The maximum elongation is in the same direction as the previous area. In this case, the rumble was described as like a mine blast. The elongated shape of this isoseismal is not dependent on the anthropic structure of the area, but is a propagation effect. It is also clear that the instrumental epicentre locations of the sequence are not comprised in this area, this fact is further evidence that the events are not generated by the same tectonic structure.

The macroseismic investigation of the two events occurred on July 12, 2001 at 10:25 p.m (GMT), and on August 25, 2001 at 10:55 a.m. (GMT), whose intensities were estimated as V MCS and V-VI MCS respectively, did not have a great success. Because of summer, most people were on holiday so we were not able to collect a sufficient number of macroseismic forms to draw up a macroseismic map. In any case, on the basis of the information we col- lected, we can affirm that the locality named Pantano was the maximum intensity area for the first event, and the locality named Collefiorito was the maximum intensity area for the second.

An event which occurred in the same zone, on January 31, 2002 at 10:50 a.m. (GMT) that had a felt area of about $10 \mathrm{~km}^{2}$ (fig. 5). In this case, the isoseismals maximum elongation is in direction NNE-SSW. Both the localities Pantano and Collefiorito felt the event remarkably. The scarcity of information in the area between the railway station and Pantano and between Pantano and San Giovanni lake did not clearly define the trend of the isoseismal. In this case also, we could affirm that the attenuation was stronger in the ENE direction than on the opposite side.

The event which occurred on November 7, 2001 at 3:06 a.m. (GMT) seems related to another seismogenetic structure (fig. 6). In effect, it is located inside the Acque Albule travertine basin but 2-3 km away from the other events considered in this study. The felt area $\left(7 \mathrm{~km}^{2}\right)$, highly populated, allowed a detailed description of the macroseismic effects. As shown in fig. 6, the isoseismals are elongated in the $\mathrm{N}-\mathrm{S}$ direction even though in this direction we have less information because it is less populated and, to the south, the presence of the travertine working quarries kept people from feeling the event. The area enclosed in the isoseismal with IV MCS degree is not symmetric with respect to the isoseismal with higher degree (V MCS). From this point of view, we can affirm that the attenuation was stronger on the eastern part than on the western. Moreover, due to very local site effects, we found sporadic small areas with intensity up to IV MCS degree randomly distributed.

During the evolution of the seismic sequence, a series of natural phenomena, certainly related to a system not in balance, was observed in the area. The first, observed by inhabitants, followed the event of June 22nd. People pointed out the leakage of gas from some points of the subsoil $200 \mathrm{~m}$ far from each other. The leakages were odourless, audible and had a consistency of vapour. Some operators identified them as $\mathrm{CO}_{2}$ emissions and excluded the presence of sul- 
$12^{\circ} 45^{\prime}$

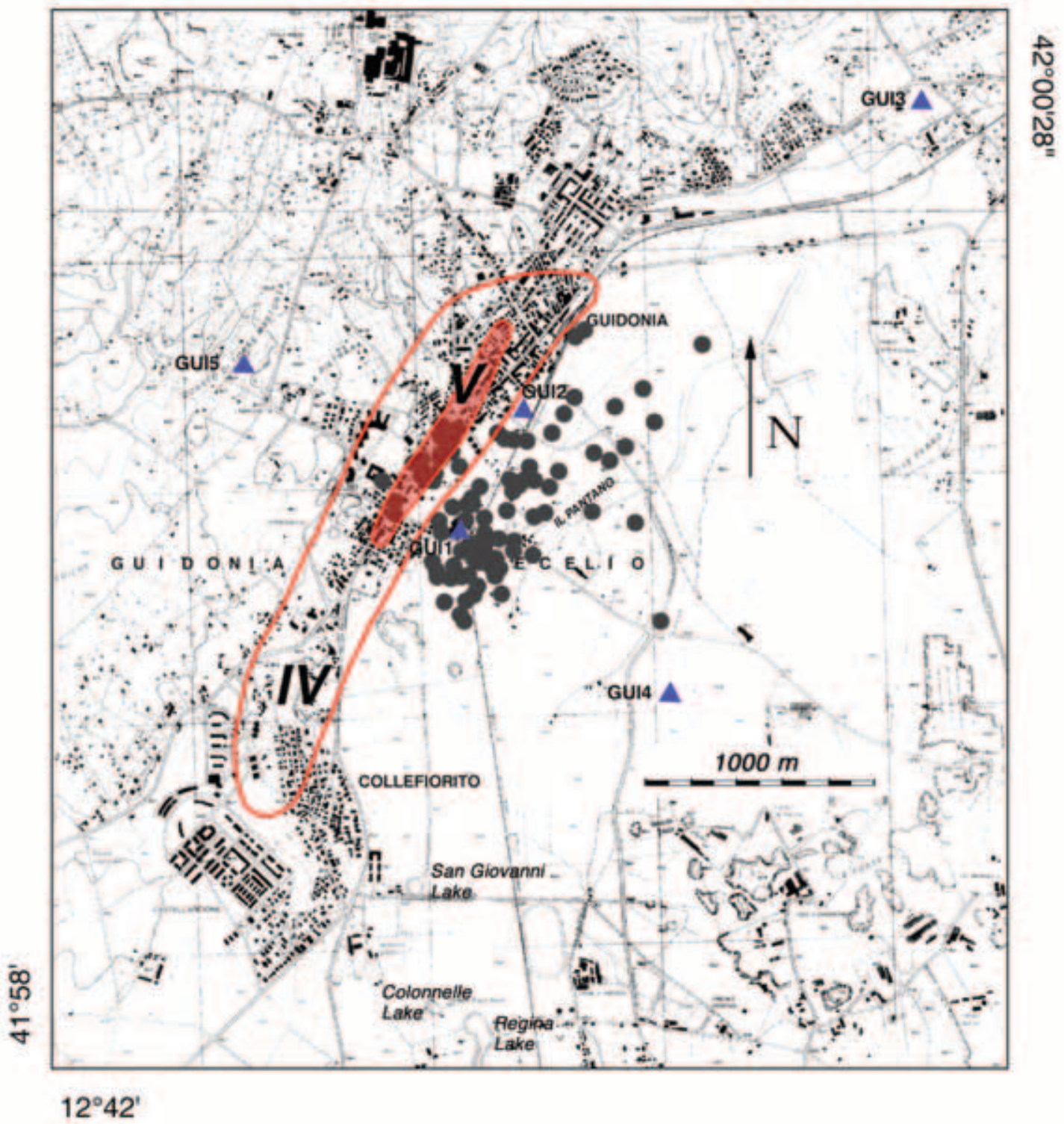

Fig. 4. Macroseismic investigation of the event which occurred on June 22, 2001 at 4:36 p.m. GMT, in addition the distribution of the events, occurring during the period May-June 2001 and recorded by the INGV mobile network. 


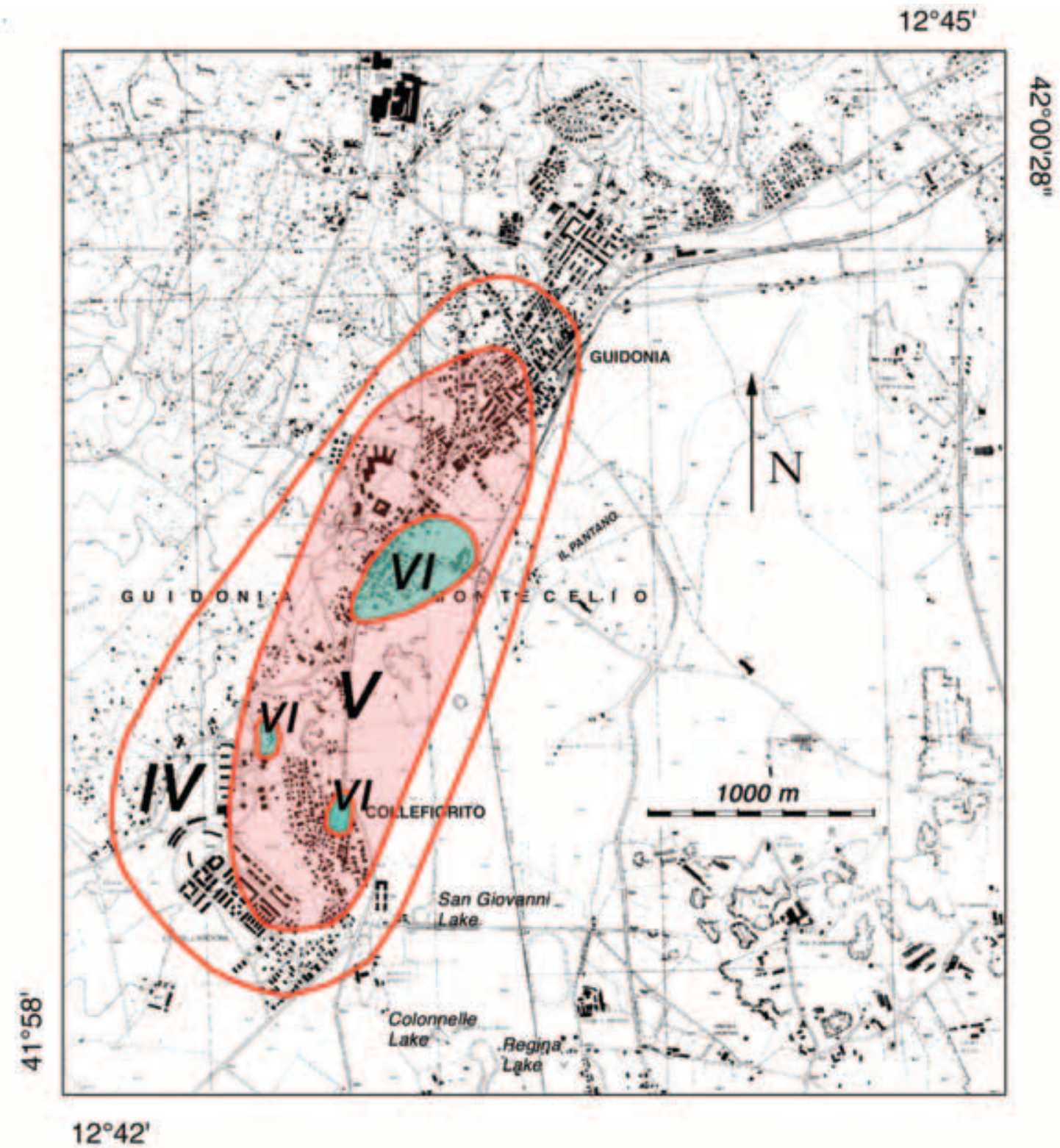

Fig. 5. Macroseismic investigation of the event which occurred on November 7, 2001 at 3:06 a.m. (GMT). 


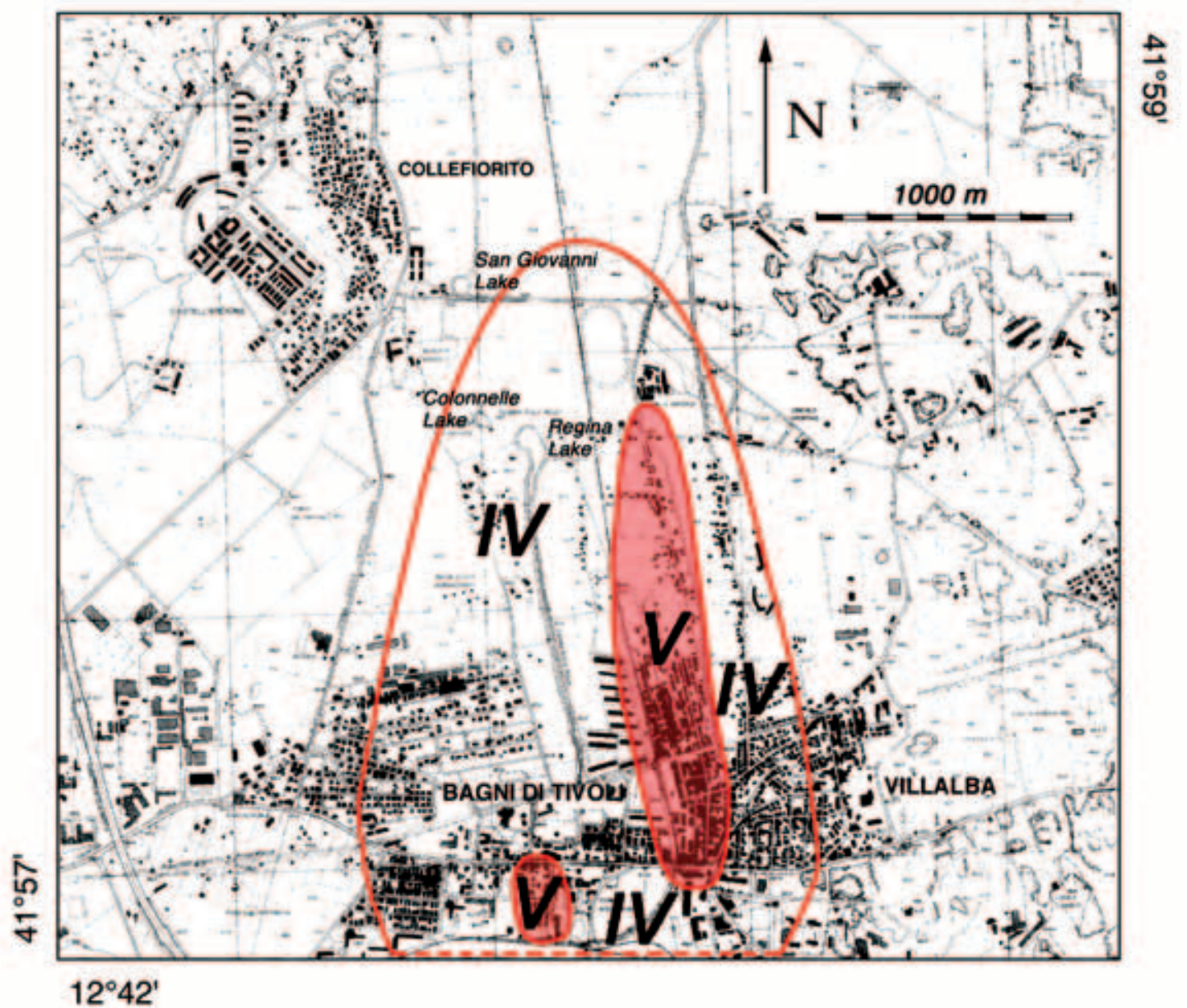

Fig. 6. Macroseismic investigation of the event which occurred on January 31, 2002 at 10:50 a.m. (GMT).

phured gas and methane. Pantano, that is inside the micro and macroseismic epicentral area, was the locality affected by this phenomenon starting in coincidence with the event and vanishing within one day.

The second phenomenon inside the Acque Albule travertine basin, was observed in coincidence with the July event and was related to a change in the hydrogeological structure. The phenomenon was pointed out by the technical office of Bagni di Tivoli thermae, that claimed a three quarter loss in the usual flow (about $3.25 \mathrm{~m}^{3} / \mathrm{s}$ ).

The new situation caused a water table overloading, but at the occurrence of the August event the usual value of the spring flows of Acque Albule (Regina and Colonnelle lakes in figs. 3, 4 and 5) had been slowly re-established. 


\section{Data set and processing}

Table II shows the seven events recorded by the National Network in the period between June 2001 and January 2002.

It was just the panic created by the frequent noises and shakes felt by the inhabitants and the event recorded by the permanent centralized network (RSNC) on June 22nd that induced INGV to install the local mobile network.

In this study, we processed the sequence recorded by the local network during the period between June 28th and July 11th. The whole recorded sequence consists of 95 events concentrated in an area of about $2 \mathrm{~km}^{2}$ named Pantano.

Among the sequences recorded by the mobile network, 65 events have been selected to locate the hypocenter. The criteria we followed for the selection was to consider events with 8 phases at minimum. The hypocenter determination was performed by the routine HYPOINVERSE, the velocity model we adopted takes into account the geology of the area:

\begin{tabular}{cc}
\hline $\begin{array}{c}\text { Thickness } \\
(\mathrm{km})\end{array}$ & $\begin{array}{c}\text { Velocity } \\
(\mathrm{km} / \mathrm{s})\end{array}$ \\
\hline $0-2$ & 2.2 \\
$2-5$ & 4.4 \\
\hline
\end{tabular}

The stratigraphy of the area was deduced from literature (Amato et al., 1986), and from deep drillings and geological survey: the travertine thickness is about $25 \mathrm{~m}$, and is over the blue clay layer that is over the Mesozoic-Cenozoic limestone bedrock, deeper than $500 \mathrm{~m}$. So the ruptures must have origin in this layer, because the rheology characteristic of the blue clay, that is more recent, cannot justify the ruptures.

We could not calculate the local magnitude because the distance function $f(\Delta)$ (published by Richter in 1935 and the one we usually use) does not hold at such short distances between station and hypocenter.

For local events, we use the magnitudeduration relation (Console et al., 1988)

$$
M d_{i}=a \cdot \log _{10}\left(\tau_{i}+c \cdot \Delta_{i}\right)-b
$$

where $a=2.0, b=0.870$ and $c=0.082 . \tau_{i}$ is the $i$-th seismic signal duration and $\Delta_{i}$ is the linear distance of the $i$-th station with respect to the epicenter determination.

The $M d$ value of a regional event is calculated as the arithmetic average among the single magnitude values, eventually removing the maximum and (/or) the minimum, if they are «very distant» from the average.

Table II. Events recorded by the Centralized National Network in the period between June 2001 and January 2002.

\begin{tabular}{|c|c|c|c|c|c|c|c|c|}
\hline Year & Month & Day & $\begin{array}{l}\text { hh:mm } \\
\text { (GMT) }\end{array}$ & Lat. (N) & Long. (E) & MCS Int. & $M d$ & Localities \\
\hline 2001 & June & 22 & $16: 36$ & 41.96 & 12.68 & V & 2.3 & $\begin{array}{l}\text { Guidonia } \\
\text { (Pantano) }\end{array}$ \\
\hline 2001 & July & 12 & $22: 23$ & 41.96 & 12.68 & V-VI & 2.7 & $\begin{array}{l}\text { Guidonia } \\
\text { (Pantano) }\end{array}$ \\
\hline 2001 & August & 25 & $10: 55$ & 41.97 & 12.70 & VI & 2.6 & Collefiorito \\
\hline 2001 & September & 1 & $19: 24$ & 41.96 & 12.68 & V & 2.3 & Pantano \\
\hline 2001 & October & 8 & $15: 00$ & 41.97 & 12.70 & III & 2.1 & Collefiorito \\
\hline 2001 & November & 7 & 03:06 & 41.96 & 12.76 & V-VI & 2.6 & Villalba \\
\hline 2002 & January & 31 & 09:50 & 41.96 & 12.68 & V-VI & 2.4 & $\begin{array}{c}\text { Pantano } \\
\text { (Collefiorito) }\end{array}$ \\
\hline
\end{tabular}




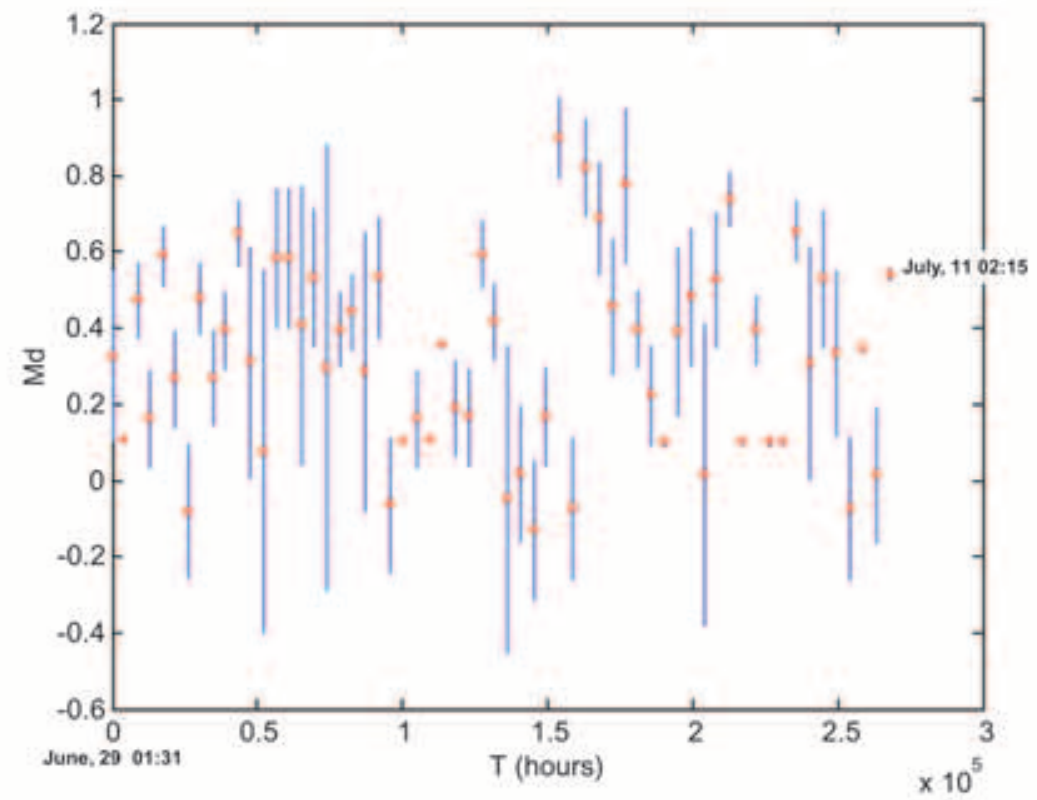

Fig. 7. Temporal evolution of the sequence. The figure indicates only the events recorded by the local network with the maximum error.

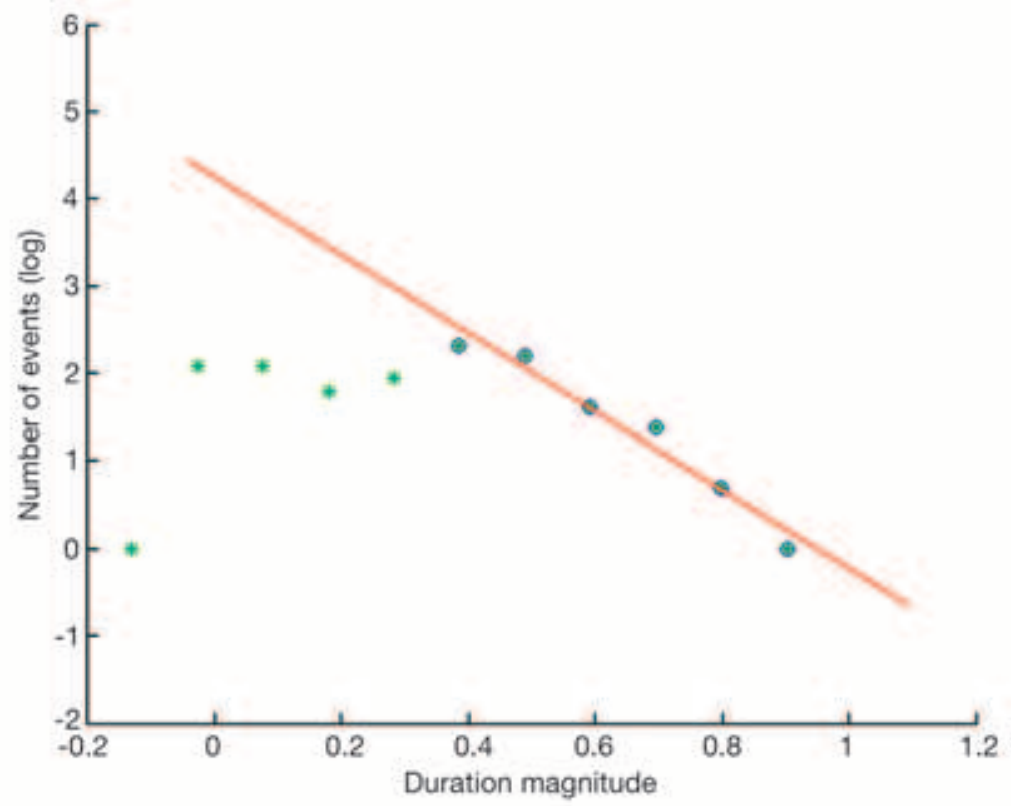

Fig. 8. Minimum magnitude of completeness $M_{C}$ of the sequence obtained plotting the cumulative number of events versus magnitude and the straight line that fit the data. 
The selected sequence has a duration magnitude between -0.1 and 0.9 .

Figure 7 shows the temporal evolution of the sequence. In the figure only the events recorded by the local network with the maximum error are indicated. The occurrences seem very regular in time, unfortunately the errors on magnitudes do not depend on the magnitude value itself, some of them are very high, some of them are very low. Probably it depends on the application of the formula, tested for regional events and not for very local and shallow events.

In order to obtain a complete view of the phenomenon, we calculated the minimum magnitude of completeness. Starting from the Gutenberg-Richter (Gutenberg-Richter, 1944) relationship

$$
\log N=a-b M
$$

the determination of the minimum magnitude of completeness $M_{C}$ of a data set is obtained plotting $\log N$ (cumulative number of events versus magnitude) and the straight line that fits the data. Following Habermann (1983), $M_{C}$ is the level at which the data fall below the line. In fig. 8 we can identify this value that for $M d$ is 0.4 .

We can write the formula as follows:

$$
\log N=4.3-4.5 M d \text {. }
$$
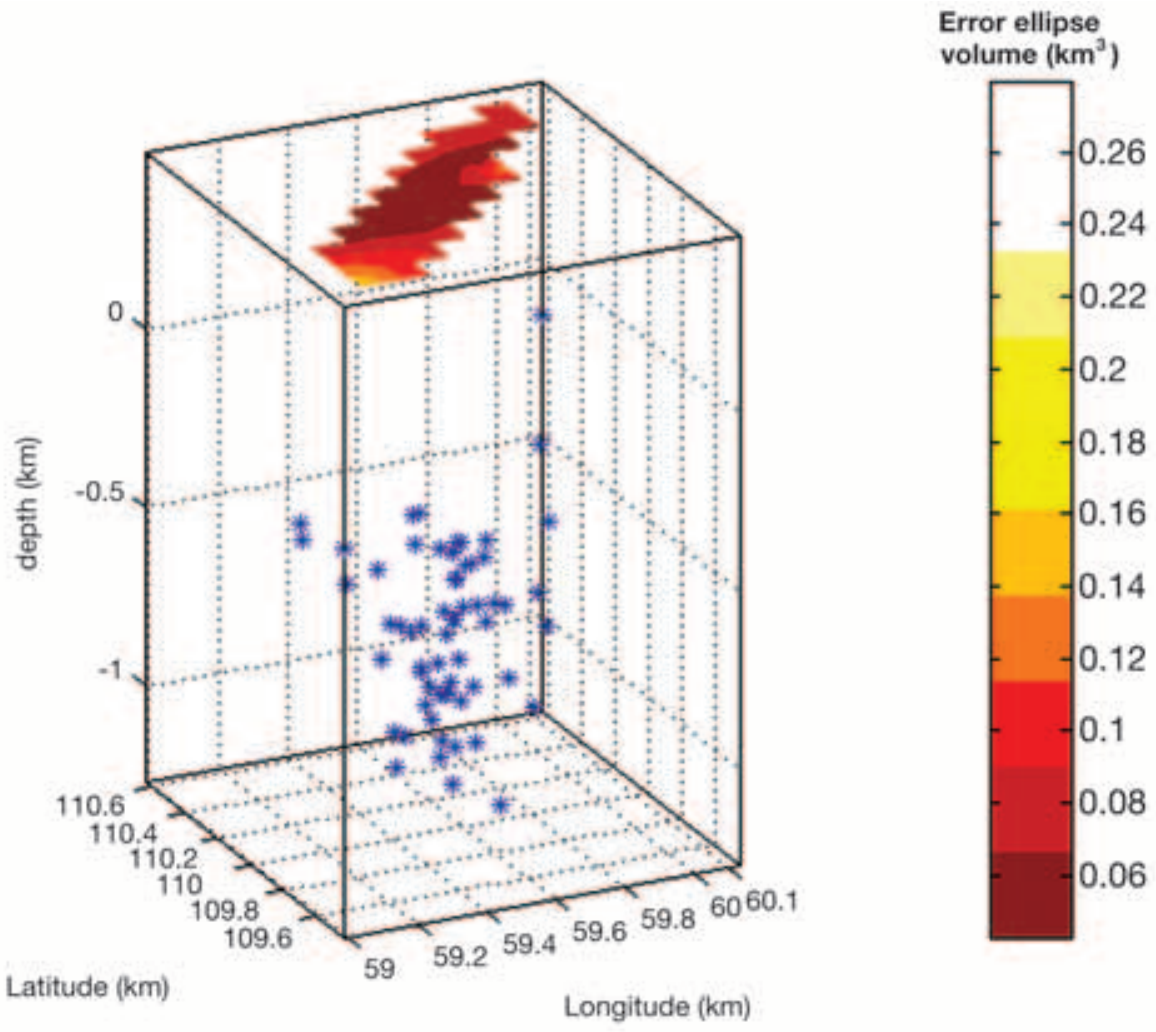

Fig. 9. Three-dimensional view of the locations with the three axes of the error ellipses, in addition a coloured evaluation of the error ellipse volumes is shown in the horizontal plane. 


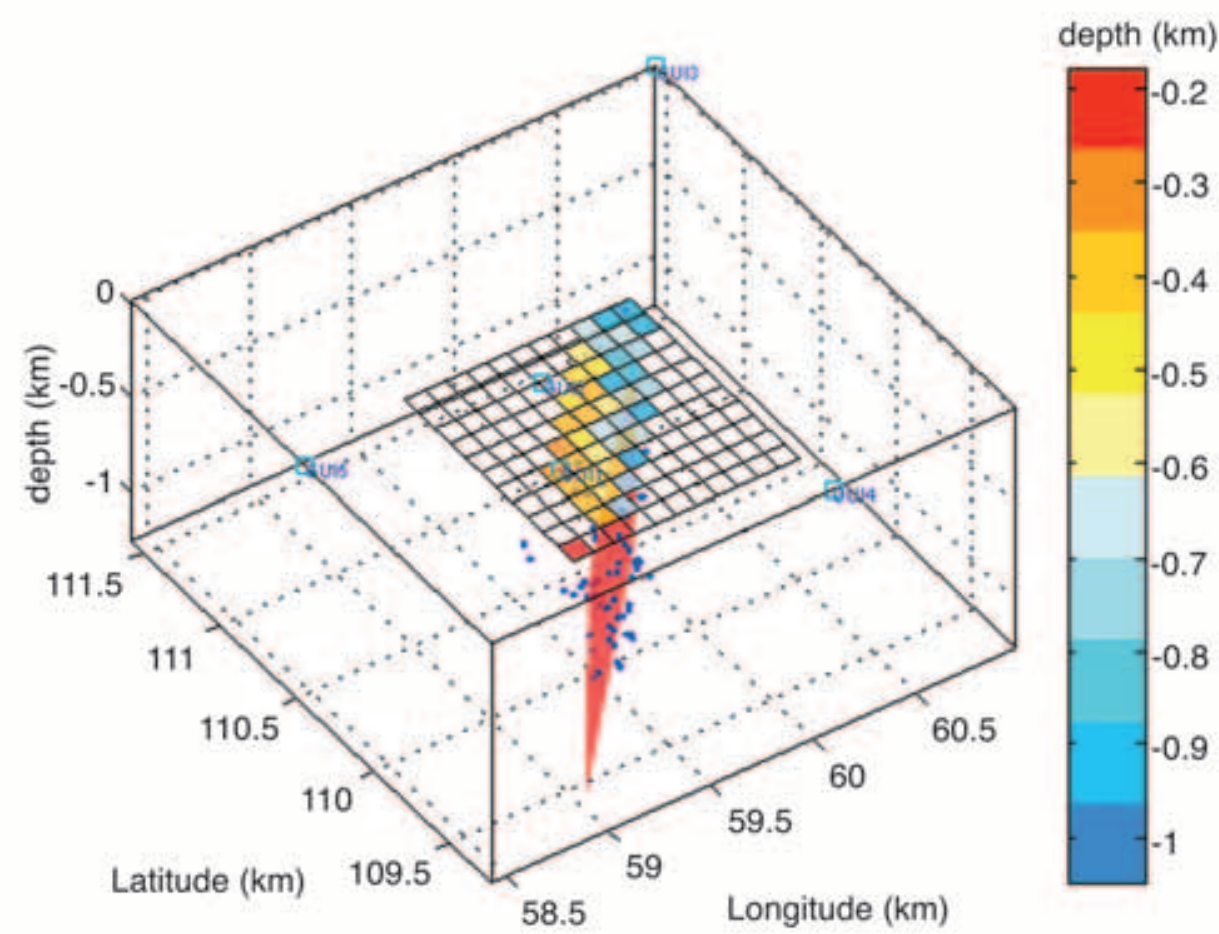

Fig. 10. Three-dimensional hypocentral locations with the stations of the local network; the horizontal plane indicates the depth of the events.

The correlation coefficient is close to 1 , and 0.9 is the expected maximum magnitude for the period under observation.

The local network had been dismounted on July 11th because of the lack of significant events, even though the sequence was still in progress. Unfortunately, on the July 12th the RSNC recorded an event with $M d=2.7$, so we do not have events recorded by both the networks (permanent and mobile) and, consequently we cannot perform any calibration of the magnitude.

Figure 9 shows the three-dimensional view of the locations. In addition, a coloured evaluation of the error ellipse volumes is shown on the horizontal plane. As shown in the figure, they are clustered and seem to lie in a plane with a certain direction.

As the hypocenters lie inside the network, the greater errors are not distributed on the border and the major axis of the ellipse has the projection on the depth $(z)$ axis. The result of the regression of the hypocentres on a plane is shown in fig. 10, it has an anti-Apennines direction, the coloured horizontal plane indicates the depth of the events, but due to the high error it is not significant.

\section{Conclusions}

The recent seismic phenomenology aroused interest in an area that historically was not significant because of the scarcity of information regarding large earthquakes.

The interpretation of macroseismic effects of the most significant events presents some difficulties related to the geological knowledge of the urban territory. Certainly the events, whose macroseismic epicentres are between Guidonia 
and Collefiorito, are characterised by some peculiar factors: the low depth of the hypocentres, the presence of the basin border with consequent surface geological formation heterogeneity and the peculiar morphological formation.

It is remarkable that the major effects are in the area where the massive travertine crops out surrounding the area of the obsolete quarries filled by waste material.

Moreover we can affirm that the seismotectonic structure that originated this events is oriented in anti-apenninic direction. This is also confirmed by the data analysis of the sequence analysed in the study: the events (fig. 9) present a good alignment in a quasi vertical plane.

In relation to the event of November 2001 that occurred in the central part of the basin, we can conclude that the seismotectonic structure that originated it, is different. This event presents the maximum elongation of the isoseismals in a $\mathrm{N}-\mathrm{S}$ direction. This suggests that the seismotectonic structure that originated it, is related to a prevalent strike slip tectonics as reported in a previous paper (Faccenna et al., 1994)

Moreover, even if the magnitude is comparable with the others, the affected area is wider, of course it depends on the depth and on the local attenuation effects.

This phenomenology, that is still ongoing, is the response of the seismotectonic system located in the middle of the Aniene valley that is not in balance. These studies are important for the characterization of the system and could be helpful to understand similar phenomena that occur in the surrounding area.

\section{REFERENCES}

Amato, A., M. Di Filippo, M. Mattei, P. Montone and R. SCARPA (1986): Interpretazione congiunta di profili gravimetrici e di sismica a rifrazione nella provincia di Roma, in Atti del LXXIII Congresso S.G.I., Roma, 57-60.

CIPRIANI, N., P. MALESANI and S. VANNUCCI(1997): I travertini dell'Italia centrale, Boll. Serv. Geol. Italia, 98, 85-115.
CONSOLE, R., B. DE SimONI and A. Di SANZA (1988): Riesame della relazione magnitudo-durata, in Atti del VII Convegno GNGTS, 30 November - 2 December, 51-62.

Cosentino, D., R. Funiciello, P. Montone, M. Parotto and M. Voltaggio (1990): Neotettonica nell'area Tiburtina, (Italia centrale, Roma), in Convegno "Irpinia Dieci Anni Dopo», novembre 1990, Napoli, abstract, 209-210.

FACCENNA, C. (1994): Structural and hydrogeological features of the Pleistocene shear zones in the area of Rome (Central Italy), Ann. Geofis., 37 (1), 121-133.

Faccenna, C. and R. Funiciello (1993): Tettonica pleistocenica tra il Monte Soratte e i Monti Cornicolani, Il Quaternario, 6 (1), 103-118.

Faccenna, C., R. Funiciello, P. Montone, M. Parotto and M. VOLTAGGIO (1994): Late pleistocene strike in the Acque Albule basin (Tivoli, Latium), Memorie Descrittive della Carta Geologica d'Italia, 49, 37-50.

Gasparini, C., A. Marchetti, N.M. PAgliuca and M. PIRRO (2001): Analisi preliminare del periodo sismico avvenuto nel territorio del Comune di Guidonia Montecelio (RM) tra il maggio e settembre 2001, in XX Convegno GNGTS, CNR, Roma (in press).

GUTENBERG-RICHTER, N. (1944): Frequency of earthquakes in California, Bull. Seismol. Soc. Am., 35, 185-188.

KEAREY, P. and J.V. FrEDERIK (1990): Global Tectonics, London, p. 302.

HABERMANN, R.E. (1983): Teleseismic detection in the Aleutin Island arc, J. Geophys. Res., 88, 5056-5064.

MaXIA, C. (1950): Il Bacino delle Acque Albule, Contributi di Scienze Geologiche, CNR, Roma, vol. 20, p. 20.

Meloni, F. and M. PIRRo (1989): Analisi Preliminare del Periodo Sismico del Gennaio 1989 in Località Collefiorito di Guidonia (Prov. di Roma). Aspetti Neotettonici, Amm. Com. Guidonia-Montecelio.

OGNiBEN, L., M. PAROTTO, A. PRATURLON (1975): Structural model of Italy, Quad. Ric. Sci., CNR, Roma, 90, 257-311.

Pellanti, R. (1882): I travertini della Campagna Romana, Boll. R. Com. Geol. d'Italia, Roma, vol. III, 82-94.

PIRRO, M. (2002): Sismicità storica e strumentale dei Monti Cornicolani e dintorni (Lazio), in Aspetti Naturalistici, Geologici e Geofisici dei Monti Cornicolani, edited by M. GIARDINI, Amm. Prov. di Roma, 141-167.

PosTPISCHL, D. (1985): Catalogo dei terremoti italiani dall'anno 1000 al 1980, Quad. Ric. Sci., CNR, Roma, 114 (2B), p. 239.

VoltagGio, M. and M. BARBIERI (1995): Geochronology, in The Volcano of the Alban Hills, Rome, edited by R. TRIGILA, 167-192.

(received April 8, 2002; accepted July 5, 2002) 